\title{
Analysis of the Fusion Protein Gene of Newcastle Disease Viruses Isolated in Japan
}

\author{
Masaji MASE ${ }^{1,2) *}$, Kazunori MURAYAMA ${ }^{3)}$, Ayako KARINO ${ }^{4)}$ and Toshikazu INOUE ${ }^{1)}$ \\ ${ }^{1)}$ National Institute of Animal Health, 3-1-5 Kannondai, Tsukuba, Ibaraki 305-0856, ${ }^{2)}$ United Graduate School of Veterinary Sciences, \\ Gifu University, 1-1 Yanagido, Gifu 501-1193, ${ }^{3)}$ Chuo Livestock Hygiene Service Center, 686 Hataya, Nishikan, Niigata $959-0423$ and \\ ${ }^{4)}$ Domestic Livestock Disease Identification Office, Shimane Prefecture, 918-4 Jinzaiokicho, Izumo, Shimane 699-0822, Japan
}

(Received 28 June 2010/Accepted 8 August 2010/Published online in J-STAGE 23 August 2010)

ABSTRACT. The complete nucleotide sequences of the fusion (F) protein gene of Newcastle disease viruses (NDV) isolated in Japan from 1930 to 2007 (45 strains total) were determined and genetically analyzed. In the deduced amino acid sequences of fusion protein, the 5 potential asparagine-linked glycosylation sites and 10 cysteine residues were all conserved in the NDV examined in this study. The major epitopes involved in virus neutralization are conserved in most of the NDV strains isolated in Japan except a few strains. By virus neutralization test, no major antigenic differences were observed among representative strains of each genotype in Japan. All chickens vaccinated with the B1 strain survived without clinical signs after challenge with 2 NDV strains isolated in Japan (velogenic strains, JP/ Ibaraki/2000 and JP/Kagoshima/91), which possess amino acids substitutions involved in virus neutralization in the $\mathrm{F}$ protein gene. KEY WORDS: antigenicity, B1 vaccine, fusion protein, Newcastle disease virus, phylogenetic analysis.

J. Vet. Med. Sci. 73(1): 47-54, 2011

Newcastle disease is one of the most serious diseases in the poultry industry. The causative agent is the Newcastle disease virus (NDV), also designated avian paramyxovirus type 1 (APMV-1), which belongs to the genus Avulavirus within the family Paramyxoviridae [3].

Paramyxovirus infection is initiated by the action of two envelope glycoproteins [20]. One of them mediates attachment of the virus to the host cell receptor and is designated hemagglutinin-neuraminidase (HN) for the paramyxovirus. The other glycoprotein, designated fusion (F), is responsible for virus penetration into the host cell and virus-induced cell fusion and hemolysis [20]. These 2 surface glycoproteins are important as the targets of the host immune response. One characteristic feature in the host immune response to paramyxovirus infection is that although antibodies to either glycoprotein can neutralize infectivity in in vitro tests, antibodies to $\mathrm{F}$ appear to be predominantly necessary and important for preventing infection and spread of the virus in vivo [31]. In passive immunization in chicks, monoclonal antibodies directed to 2 antigenic sites of the F protein completely suppressed virus growth and prevented the death of chickens [41]. Therefore, the F protein gene of NDV was selected to construct a candidate of the DNA vaccine or recombinant vaccine expressing this gene and proved to efficiently protect against challenge with the virulent NDV strains $[22,38,39]$. The 5 major epitopes were mapped on the F protein of NDV, which was involved in fusion inhibition and neutralization $[40,43]$. Toyoda et al. and Yusoff et al. found that the stretch of amino acids from residues 157171 and individual residues 72, 78, 79 and 343 were critical for both the structures and functions of these epitopes.

To date, phylogenetic analysis based on the genomic

\footnotetext{
* Correspondence to: Mase, M., Research Team for Zoonotic Diseases, National Institute of Animal Health, 3-1-5 Kannondai, Tsukuba, Ibaraki 305-0856, Japan.

e-mail: masema@affrc.go.jp
}

sequences have revealed that the strains of NDV could be divided into 2 distinct clades, class I and class II, and that each clade contains nine genotypes (1-9 and I-IX, respectively) $[11,17,18]$. Among them, class II NDV strains have been responsible for most of the outbreaks of ND reported throughout the world; in particular, strains of genotype VII (class II) are regarded as the major pathogen responsible for the recent outbreaks in eastern Asia, including Japan [19, $21,23-25,27,28]$. On the other hand, most of the class I isolates have been obtained from waterfowl, shorebirds or poultry from live bird markets in Asia or America [17, 18].

Previously, based on phylogenetic analysis of the abovementioned F protein genes, NDV strains isolated in Japan could be classified into 6 genotypes of class II (I-III, VI, VII and VIII) $[27,28]$, suggesting that the NDV strains in Japan are genetically diverse. However, a full analysis of the amino acids related to these important epitopes located in the $\mathrm{F}$ protein gene involved in fusion inhibition and neutralization has not been performed. Therefore, we determined the full length of the F protein gene of NDV strains in Japan and mainly examined the amino acid residues of epitopes involved in neutralization of the NDV. Additionally, the efficiency of protection of live vaccine strain B1 was evaluated against isolated NDV strains from chickens in Japan.

\section{MATERIALS AND METHODS}

Viruses: A total of 45 Japanese NDV strains isolated from 1930 to 2007 were used and described previously (all viruses belonged to class II) $[27,28]$ (Table 1). The allantoic cavities of specific-pathogen-free (SPF) embryonated eggs were used for virus propagation, and the allantoic fluids were then stored at $-80^{\circ} \mathrm{C}$ until use.

Genetic analysis of $F$ protein gene: Viral RNA was extracted from the infected allantoic fluids using a kit (ISOGEN-LS, Nippon Gene, Tokyo, Japan). A reverse 
Table 1. NDV strains used in this study

\begin{tabular}{|c|c|c|c|}
\hline Virus & Abbreviation & Isolation year & Genotype \\
\hline APMV1/chicken/Japan/Sato/30 & $\mathrm{JP} / \mathrm{Sato} / 30$ & 1930 & III \\
\hline APMV1/chicken/Japan/Miyadera/51 & JP/Miyadera/51 & 1951 & II \\
\hline APMV1/chicken/Japan/Ishii/62 & JP/Ishii/62 & 1962 & I \\
\hline APMV1/Japanese blue magie/Japan/Narashino/68 & $\mathrm{JP} /$ Narashino/68 & 1968 & VI \\
\hline APMV1/chicken/Japan/Chiba/69 & $\mathrm{JP} / \mathrm{Chiba} / 69$ & 1969 & VI \\
\hline APMV1/pigeon/Japan/Ibaraki/84 & JP/Ibaraki-pg/84 & 1984 & VI \\
\hline APMV1/chicken/Japan/Ibaraki/85 & $\mathrm{JP} / \mathrm{Ibaraki} / 85$ & 1985 & VI \\
\hline APMV1/pheasant/Japan/Tochigi/ 85 & JP/Tochigi-ph/85 & 1985 & VI \\
\hline APMV1/chicken/Japan/TY-1/85 & JP/TY-1/85 & 1985 & VI \\
\hline APMV1/pheasant/Gunma/85 & JP/Gunma-ph/85 & 1985 & VII \\
\hline APMV1/chicken/Japan/Hyogo/85 & JP/Hyogo/85 & 1985 & VII \\
\hline APMV1/chicken/Japan/Niigata/85 & JP/Niigata/85 & 1985 & VII \\
\hline APMV1/chicken/Japan/Saitama/85 & JP/Saitama/85 & 1985 & VII \\
\hline APMV1/chicken/Japan/Shizuoka/85 & JP/Shizuoka/85 & 1985 & VII \\
\hline APMV1/chicken/Japan/Wakayama/85 & JP/Wakayama/85 & 1985 & VII \\
\hline APMV1/pigeon/Japan/Tochigi/86 & JP/Tochigi-pg/86 & 1986 & VI \\
\hline APMV1/chicken/Japan/Chiba/86 & JP/Chiba/86 & 1986 & VII \\
\hline APMV1/chicken/Japan/Chiba/87 & JP/Chiba/87 & 1987 & VII \\
\hline APMV1/pigeon/Japan/Niigata/88 & JP/Niigata-pg/88 & 1988 & VI \\
\hline APMV1/chicken/Japan/Nara/89 & JP/Nara/89 & 1989 & VII \\
\hline APMV1/chicken/Japan/Niigata/89 & JP/Niigata/89 & 1989 & VII \\
\hline APMV1/pigeon/Japan/Kushiro/91 & JP/Kushiro-pg/91 & 1991 & VI \\
\hline APMV1/chicken/Japan/Kagoshima/91 & $\mathrm{JP} /$ Kagoshima/91 & 1991 & VIII \\
\hline APMV1/chicken/Japan/Okinawa/91 & JP/Okinawa/91 & 1991 & VIII \\
\hline APMV1/chicken/Japan/MET/95 & JP/MET/95 & 1995 & II \\
\hline APMV1/pigeon/Japan/Kumamoto/95 & JP/Kumamoto-pg/95 & 1995 & VI \\
\hline APMV1/pigeon/Japan/Tochigi/95 & JP/Tochigi-pg/95 & 1995 & VI \\
\hline APMV1/pigeon/Japan/Shiga/96 & JP/Shiga-pg/96 & 1996 & VI \\
\hline APMV1/parakeet/Japan/Chiba/97 & JP/Chiba-pa/97 & 1997 & VI \\
\hline APMV1/pheasant/Ibaraki/97 & JP/Ibaraki-ph/97 & 1997 & VII \\
\hline APMV1/chicken/Japan/Ibaraki/1/99 & JP/Ibaraki-1/99 & 1999 & VII \\
\hline APMV1/pigeon/Japan/Gunma/2000 & JP/Gunma-pg/2000 & 2000 & VI \\
\hline APMV1/chicken/Japan/Ibaraki/2000 & $\mathrm{JP} / \mathrm{Ibaraki} / 2000$ & 2000 & VII \\
\hline APMV1/pigeon/Japan/Kumamoto/2001 & JP/Kumamoto-pg/2001 & 2001 & VI \\
\hline APMV1/chicken/Japan/Ibaraki/254/2001 & JP/Ibaraki-254/2001 & 2001 & VII \\
\hline APMV1/chicken/Japan/Nagano/2001 & JP/Nagano/2001 & 2001 & VII \\
\hline APMV1/chicken/Japan/Ibaraki/258/2001 & JP/Ibaraki-258/2001 & 2001 & VII \\
\hline APMV1/duck/Japan/Hyogo/2002 & JP/Hyogo-dk/2002 & 2002 & I \\
\hline APMV1/pigeon/Japan/Shizuoka/2002 & JP/Shizuoka-pg/2002 & 2002 & VI \\
\hline APMV1/chicken/Japan/Okayama/1/2001 & JP/Okayama-1/2002 & 2002 & VII \\
\hline APMV1/pigeon/Japan/Saitama/2003 & JP/Saitama-pg/2003 & 2003 & VI \\
\hline APMV1/chicken/Japan/Fukuoka/1/2004 & JP/Fukuoka/1/2004 & 2004 & VII \\
\hline APMV1/laughing kookaburra/Japan/Nara/2005 & JP/Nara-lk/2005 & 2005 & VI \\
\hline APMV1/cormorant/Japan/Gifu-Ibaraki/2005 & JP/Gifu-Ibaraki/cor/2005 & 2005 & VII \\
\hline APMV1/pigeon/Japan/Niigata/2007 & JP/Niigata-pg/2007 & 2007 & VI \\
\hline
\end{tabular}

transcriptase (RT) reaction was carried out with Superscript III (Life Technologies, Gaithersburg, MD, U.S.A.) using random 9-mers. The primers for the PCRs used for this study are listed in Table 2 . PCR was performed using 35 cycles of $94^{\circ} \mathrm{C}$ for $30 \mathrm{sec}, 55^{\circ} \mathrm{C}$ for $30 \mathrm{sec}$ and $72^{\circ} \mathrm{C}$ for 30 sec. Each PCR product was purified with Montage (Millipore, Billerica, MA, U.S.A.) according to the manufacturer's instructions. The purified PCR products were used as a template for sequencing on an Applied Biosystems 3100 automated DNA sequencer using dye terminator cycle sequencing chemistry (Applied Biosystems, Foster City, CA, U.S.A.). The purified PCR products were sequenced from both directions. The derived nucleotide sequences were analyzed using GENETYX-Mac ver. 13.0 (Software Development Corp., Tokyo, Japan). Sequences of the NDV strains were aligned with the ClustalX program, and phylogenetic trees were constructed by the neighbor-joining method as described previously [27]. To assess the genetic diversity, including the possibility of recombination in this gene $[35,36]$, among the NDV strains, phylogenetic trees were constructed with two portions (nt 47 to 751 and nt 752 to 1708 ) of the F protein gene (Fig. 1a and $1 \mathrm{~b}$ ).

Virus neutralization test (VNT): To understand the differences of antigenicity among NDV strains belonging to each genotype, a virus neutralization test using three antisera against NDV [12] was performed by microneutralization 
Table 2. List of RT-PCR and sequencing primers

\begin{tabular}{llc}
\hline Name & Primer sequence (5'-3') & $\begin{array}{c}\text { Genomic site in B1/47 } \\
\text { (Acc No. AF309418) }\end{array}$ \\
\hline ND-19F & TTCTCTAGCAGTGGGACAGC & $4,169-4,188$ \\
ND-26F & TGGAGCCAAACCGCGCACCTGCGG & $4,235-4,258$ \\
ND-14F & TTAATGGCAGGCCTCTTGC & $4,638-4,656$ \\
ND-10F & CTTTGCTCACCCCCCTTGG & $4,812-4,830$ \\
ND-15R & GGAGGATGTTGGCAGCATT & $5,000-4,982$ \\
ND-11R & CATCTTCCCAACTGCCACTG & $5,089-5,070$ \\
ND-1F & AACCCTATTCTGTACGACTCAC & $5,357-5,378$ \\
ND-23F & AGGCTCAGTGGGGAATTTGATG & $5,846-5,867$ \\
ND-4R & AACGATATAGGTGATGAGAGC & $6,061-6,041$ \\
ND-25R & ATCCGGAAAACCAGGCGCCATGT & $6,491-6,469$ \\
\hline
\end{tabular}

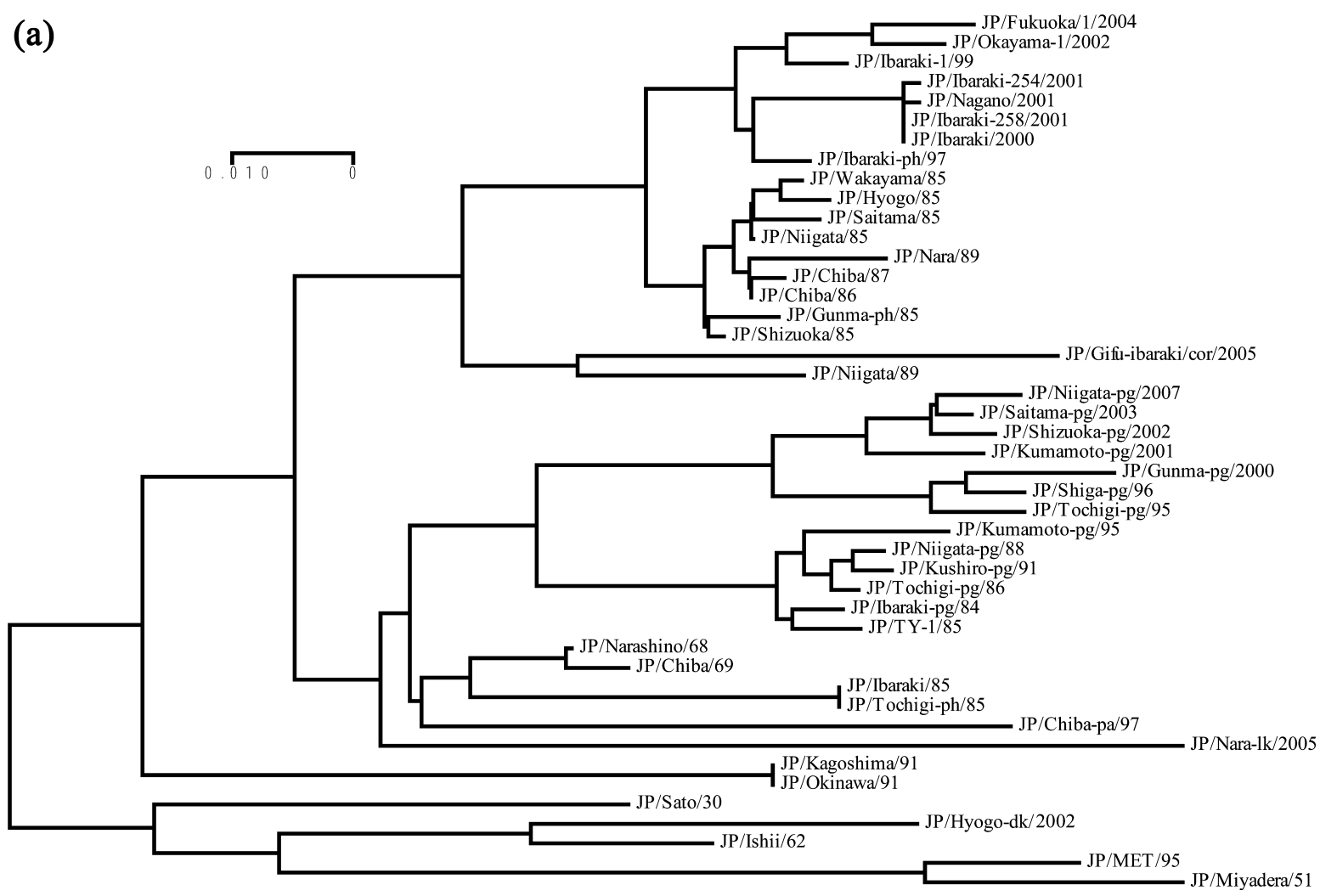

Fig. 1a. Phylogenetic tree of NDV isolates based on nucleotide sequences from a portion (nt 47 to 751 ) of the F gene. The horizontal distances are proportional to the minimum number of nucleotide differences required to join nodes and sequences.

methods with 48-well plates. Briefly, the constant virus and varying serum technique was employed in which two hundred $50 \%$ tissue culture-infected doses $\left(\mathrm{TCID}_{50}\right)$ of virus isolates and twofold dilutions of antisera, starting from 1:4, were used. Two wells were used per virus-serum mixture. The neutralization titers were read one week after inoculation, and the reciprocal of the highest dilution of the serum showing a $50 \%$ endpoint of neutralization was used.

Cross-protection experiments using the B1 strain against isolated NDV from chickens in Japan: The B1 strain is mainly used for commercial poultry flocks in Japan. The effect of the B1 strain used as a live vaccine strain was eval- uated against NDV isolates in Japan according to method reported previously [12]. Two NDV isolates (JP/Ibaraki/ 2000 and JP/Kagoshima/91, which were classified into genotypes VII and VIII, respectively) were used in this experiment because both strains possessed amino acid substitutions involved in virus neutralization as described later. Four-week-old specific pathogen free chicks (line M, Nisseiken, Hokuto, Japan) were vaccinated with the B1 strain orally $\left(10^{6} \mathrm{EID}_{50}, 0.2 \mathrm{ml} /\right.$ bird $)$. Two weeks later, the birds were challenged by the intratracheal route with live JP/ Ibaraki/2000 and JP/Kagoshima/91 ( $\left.10^{4} \mathrm{EID}_{50}, 0.1 \mathrm{ml} / \mathrm{bird}\right)$. The birds were placed in a negatively pressured house with 


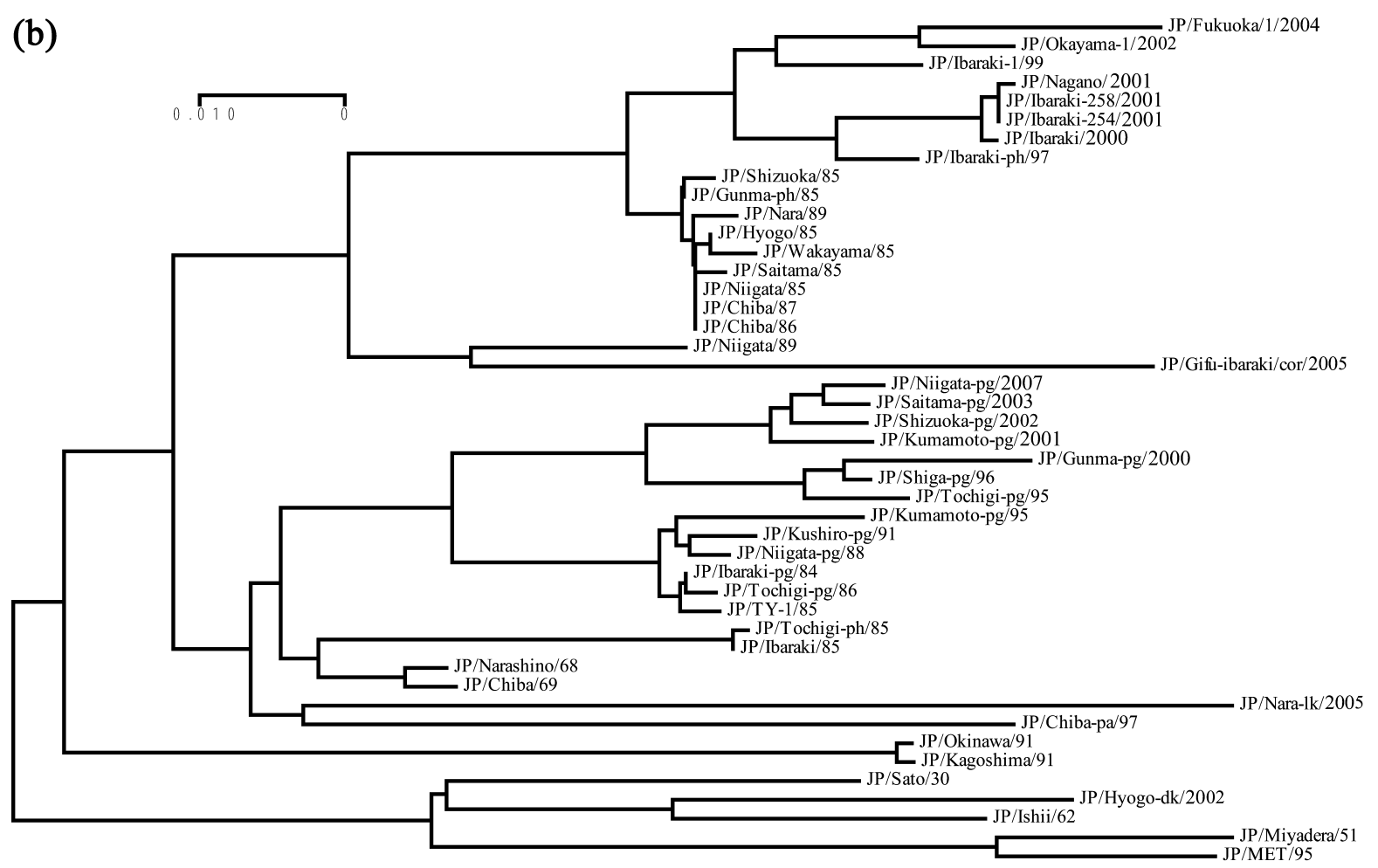

Fig. 1b. Phylogenetic tree of NDV isolates based on nucleotide sequences from a portion (nt 752 to 1708) of the F gene. The horizontal distances are proportional to the minimum number of nucleotide differences required to join nodes and sequences.

high efficiency particulate air-filtered intakes and exhaust. All chicks were observed daily for 14 days, and overt clinical signs (edema, muscular tremors, torticollis and paralysis of wings and legs) and/or deaths were recorded. Tracheal and cloacal swabs were taken from each chicken at 3 days post-challenge for virus isolation to examine excretion of the virus. The swabs were frozen at $-80^{\circ} \mathrm{C}$ and later thawed for ease of handling. Solid debris was pelleted by centrifugation, and the supernatants were titrated for virus infectivity in primary chicken kidney cell cultures (CKCs). CKCs were cultured as described previously [13]. Serum samples for a hemagglutination inhibition (HI) assay to detect antibodies to NDV were taken by wing bleed before and after the challenge. All experimental procedures and animal care were performed in compliance with the guidelines of the National Institute of Animal Health for the humane use of laboratory animals.

\section{RESULTS}

Nucleotide sequencing and sequence analysis: The amplified $\mathrm{F}$ protein gene coding sequence for each strain was 1662 nucleotides, directing the synthesis of a protein predicted to be 553 amino acids in length. The 5 potential asparagine-linked glycosylation sites (positions 85, 191, 366,447 and 471) and 10 cysteine residues (positions 76, $199,338,347,362,370,394,399,401$ and 424) [6, 30] were all conserved in NDV strains in Japan.

The stretch of amino acids from residues 157-171 and individual residues D72, K78, A79 and L343, which are involved in virus neutralization, have been identified in previous studies [33, 40, 43]. These amino acids are highly conserved among the NDV strains used in this study with some exceptions. Some of the 2000-2001 isolates (JP/Ibaraki/2000, JP/Ibaraki-254/2001 and JP/Nagano/2001 strains, which were classified into genotype VII) possessed an amino acid substitution at position 78 ( $\mathrm{K}$ to $\mathrm{R}$ ). The genotype VIII strains (JP/Kagoshima/91 and JP/Okinawa/91) strains possessed an amino acid substitution at position 79 (A to $\mathrm{T}$ ) in addition to 78 ( $\mathrm{K}$ to $\mathrm{R}$ ). Some isolates from pigeons, which were classified into genotype VI, possessed an amino acid substitution at position 170 (D to N; Table 3).

Phylogenetic analysis: The NDV strains are displayed in the 2 trees as belonging to the same genotypes, showing that each of the 2 regions in the $\mathrm{F}$ protein gene can be used to determine phylogenetic relatedness among NDV strains in Japan. Both trees share a very similar topology, indicating that no recombinant events occurred between $\mathrm{F}$ protein genes to generate strains of different lineage.

Virus neutralization test: The results of the cross-neutralization tests are shown in Table 4. No major antigenic differences were observed among representative strains of each genotype in Japan.

Cross-protection experiments: It has been suggested that 
Table 3. Amino acids involved in neutralization sites of representative genotypes NDV in Japan

\begin{tabular}{|c|c|c|c|c|c|c|c|c|c|c|c|c|c|c|c|c|c|c|c|c|}
\hline \multirow{3}{*}{ Virus } & \multicolumn{20}{|c|}{ Amino acids position at } \\
\hline & Genotype & 72 & 78 & 79 & 157 & 158 & 159 & 160 & 161 & 162 & 163 & 164 & 165 & 166 & 167 & 168 & 169 & 170 & 171 & 343 \\
\hline & & $\mathrm{D}$ & $\mathrm{K}$ & A & $\mathrm{S}$ & I & A & A & $\mathrm{T}$ & $\mathrm{N}$ & $\mathrm{E}$ & A & V & $\mathrm{H}$ & $\mathrm{E}$ & V & $\mathrm{T}$ & $\mathrm{D}$ & $\mathrm{G}$ & $\mathrm{L}$ \\
\hline JP/Hyogo-dk/2002 & I & . & . & . & . & . & . & . & . & . & . & . & . & . & & . & . & . & . & . \\
\hline JP/Miyadera/51 & II & . & . & . & . & . & . & . & . & . & . & 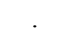 & . & . & & . & . & . & . & 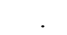 \\
\hline $\mathrm{JP} / \mathrm{Sato} / 30$ & III & . & . & . & . & . & . & . & . & . & . & . & . & . & . & . & . & . & . & 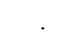 \\
\hline JP/Narashino/68 & VI & . & . & . & . & . & . & . & . & . & . & . & . & . & . & . & . & 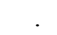 & . & . \\
\hline JP/Ibaraki-pg/84 & VI & . & . & . & . & . & . & . & . & . & . & . & . & . & . & . & . & $\mathrm{N}$ & . & . \\
\hline JP/Nara-lk/2005 & VI & . & . & . & . & . & . & . & . & . & . & . & . & . & . & . & . & 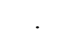 & . & . \\
\hline JP/Niigata-pg/2007 & VI & . & . & . & . & . & . & . & . & . & . & . & . & . & . & . & . & $\mathrm{N}$ & . & . \\
\hline JP/Shizuoka/85 & VII & . & . & . & . & . & . & . & . & . & . & . & . & . & . & . & . & . & . & . \\
\hline $\mathrm{JP} / \mathrm{Ib}$ baki/2000 & VII & . & $\mathrm{R}$ & . & . & . & . & . & . & . & . & . & . & . & & . & . & . & . & . \\
\hline JP/Fukuoka/1/2004 & VII & . & . & . & . & . & . & . & . & . & . & . & . & . & & . & . & . & . & . \\
\hline JP/Kagoshima/91 & VIII & . & $\mathrm{R}$ & $\mathrm{T}$ & . & . & . & . & . & . & . & . & . & . & & . & r. & . & . & 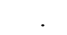 \\
\hline
\end{tabular}

Table 4. Results of the cross-neutralization test among NDV strains

\begin{tabular}{lcccc}
\hline \multirow{2}{*}{ Viruses } & \multirow{2}{*}{ Genotype } & \multicolumn{3}{c}{ Antiserum against } \\
\cline { 3 - 5 } & & B1/47 & JP/Sato/30 & JP/Shizuoka/85 \\
\hline JP/Hyogo-dk/2002 & I & 64 & 1024 & 2048 \\
JP/Miyadera/51 & II & 128 & 1024 & 2048 \\
JP/Sato/30 & III & 64 & 2048 & 1024 \\
JP/Narashino/68 & VI & 64 & 1024 & 2048 \\
JP/Ibaraki-pg/84 & VI & 32 & 256 & 2048 \\
JP/Nara-lk/2005 & VI & 64 & 256 & 256 \\
JP/Niigata-pg/2007 & VI & 16 & 128 & 512 \\
JP/Shizuoka/85 & VII & 64 & 1024 & 4096 \\
JP/Ibaraki/2000 & VII & 64 & 128 & 512 \\
JP/Fukuoka/1/2004 & VII & 64 & 256 & 256 \\
JP/Kagoshima/91 & VIII & 32 & 512 & 2048 \\
\hline
\end{tabular}

Table 5. Results of vaccinating chickens with B1 and challenging them with JP/Ibaraki/2000 and JP/Kagoshima/91

\begin{tabular}{|c|c|c|c|c|c|c|c|c|}
\hline \multirow[t]{2}{*}{ Group } & \multirow[t]{2}{*}{ Immunity } & \multirow[t]{2}{*}{ Challenge } & \multicolumn{2}{|c|}{ Number of chickens } & \multicolumn{2}{|c|}{ HI titers } & \multicolumn{2}{|c|}{$\begin{array}{l}\text { Recovery of virus at PID3 (No. of chickens } \\
\text { with virus/No. tested }\left(\log _{10} \text { TCID }_{50} / \mathrm{m} l\right)\end{array}$} \\
\hline & & & Sick & Dead & Pre-challenge & Post-challenge & Tracheal & Cloaca \\
\hline 1 & + & $\mathrm{JP} / \mathrm{Ibaraki} / 2000$ & $0 / 5$ & $0 / 5$ & $2-6\left(4^{b)}\right)$ & $6-12(10.8)$ & $3 / 5(2.7 \pm 2.0)^{\mathrm{c})}$ & $1 / 5(0.75)$ \\
\hline 2 & - & JP/Ibaraki/2000 & $5 / 5$ & $5 / 5\left(5.2^{\mathrm{a})}\right)$ & $<2$ & NT & $5 / 5(3.3 \pm 0.8)$ & $4 / 5(2.3 \pm 0.6)$ \\
\hline 3 & + & JP/Kagoshima/91 & $0 / 5$ & $0 / 5$ & $2-5(3.6)$ & $12-13$ (12.4) & $5 / 5(2.9 \pm 1.4)$ & $1 / 5(2.0)$ \\
\hline 4 & - & JP/Kagoshima/91 & $5 / 5$ & $5 / 5(5.4)$ & $<2$ & NT & $5 / 5(4.1 \pm 1.6)$ & $3 / 5(2.7 \pm 0.9)$ \\
\hline
\end{tabular}

a) Mean death time in days.

b) Geometric mean HI titers.

$\mathrm{HI}$ titers are expressed as $\log _{2}$ of the reciprocal of the highest dilution completely inhibiting $4 \mathrm{HAU}$ of virus.

$\mathrm{HI}$ titers were recorded using the JP/Ishii/62 strain as the antigen.

c) Mean \pm SD for the number of virus-positive chickens.

ND outbreaks in vaccinated poultry flocks are due to the emergence of antigenic variants $[16,42]$. To investigate this issue, we conducted the protection test using the $\mathrm{B} 1$ vaccine strain against two isolates (JP/Ibaraki/2000 and JP/ Kagoshima/91). All chickens vaccinated with the B1 strain survived without clinical signs after challenge with 2 NDV isolates in Japan, whereas all unvaccinated control chickens challenged with the JP/Ibaraki/2000 and JP/Kagoshima/91 strains died within 6 days. However, vaccination did not prevent infection and excretion of either challenge virus (Table 5). When compared with unvaccinated chickens, vaccination reduced the proportion of swabs that were positive and the titers of excreting virus.

\section{DISCUSSION}

Antibodies to epitopes on either the $\mathrm{F}$ or $\mathrm{HN}$ protein of NDV may result in neutralization of infectivity $[1,2,7,14$, 32, 33, 37]. However, while single mAbs directed to sites on the $\mathrm{F}$ protein have shown strong neutralizing activity, neutralization by individual $\mathrm{HN} \mathrm{mAbs}$ has been shown to be incomplete, requiring antibodies to 4 sites for complete neu- 
tralization [14]. In passive immunization in chicks, the mAbs directed to the $\mathrm{F}$ protein had a protective effect against challenge with virulent NDV $[32,41]$. Therefore, the importance of antibodies to $\mathrm{F}$ protein for vaccine protection against ND has been emphasized [29], and it is important to understand the genetic diversity of the $\mathrm{F}$ protein gene of field NDV strains to evaluate and develop an effective vaccine against NDV.

Here, we examined the NDV strains isolated from 1930 to 2007 in Japan on the basis of molecular analysis of the F protein gene. The amplified $\mathrm{F}$ protein gene coding sequence for all strains was 1662 nucleotides and encoded one long open reading frame of 553 amino acids in length. These results showed that deletions and insertions did not occur in the NDV strains used in this study. Furthermore, five potential asparagines-linked glycosylation sites and ten cysteine residues were conserved in NDV strains used in this study, suggesting that the F protein of NDV was highly conserved in length among all strains. These results were consistent with those of other previously analyzed strains of NDV [6, $16,42]$.

On the other hand, a recombinant variant in the $\mathrm{F}$ protein gene of NDV was recently reported in China [35, 36]. Qin et al. described that the recombination was found in the $\mathrm{F}$ protein gene of the SRZ03 strain isolated in China. By analysis of complete nucleotide sequences of this strain, they revealed that the N-terminal of this strain's F protein gene originated from a genotype II NDV strain, whereas the Cterminus of the $\mathrm{F}$ protein gene and the rest of the genes originated from a genotype VII NDV strain. Previously, we reported that NDV strains in Japan were genetically close to foreign isolates, particularly those from Korea and China $[27,28]$. Hence, we compared the two portions of the F protein genes of NDV. Our analysis showed no recombination occurred in the F protein gene, showing that such recombinant variant have not been introduced into Japan.

The 5 major epitopes on the F protein of NDV were previously mapped $[40,43]$. The stretch of amino acids from residues 157-171 and individual residues 72, 78, 79 and 343 were critical for both the structures and functions of these epitopes [8]. With some exceptions, these amino acids are conserved in the NDV strains used in this study. This is in good agreement with the results of a VNT including anti-B1 strain (live vaccine strain) sera, suggesting that no major antigenic differences were observed among representative strains of each genotype in Japan.

On the other hand, point amino acid substitutions at residues 78 and 79 in the $F$ protein were identified in the strains of NDV genotype VIII (JP/Kagoshima/91 and JP/Okinawa/ 91), and some reports have suggested that such amino acid substitutions have an influence on the antigenicity and effect of a vaccine [16, 42]. However, our cross-protection test showed that vaccination of chickens by using the B1 strain protected them against the challenge with viruses (JP/Ibaraki/2000 and JP/Kagoshima/91) with such point amino acid substitutions in the $\mathrm{F}$ protein. A previous cross-protection report [12] also demonstrated that vaccination of chickens by using the B1 strain protected the chickens against challenge with viruses of genotype VI and VII strains isolated in 1985, which do not possess amino acid substitutions on the 5 epitopes involved in neutralization according to the analysis in the present study. Furthermore, vaccination of chickens using the B1 strain protects chickens against challenge with isolates from pigeons $[10,34]$. These results and previously published reports $[4,15,26]$ suggest that antigenic variants, which fail to be neutralized by antibodies induced by conventional vaccines, would be unlikely to arise easily as described by others [9] and suggest that analysis of the F protein gene is important in estimating the emergence of antigenic variants.

However, as previously reported $[5,15]$, vaccination did not prevent infection and excretion of either challenge virus. Protection against ND is dependent on the immune status of the vaccinated flocks [15], and therefore, it would be important to develop an effective vaccine that is able to produce and maintain a high antibody level in vaccinated flocks.

\section{REFERENCES}

1. Abenes, G., Kida, H. and Yanagawa, R. 1986. Antigenic mapping and functional analysis of the F protein of Newcastle disease virus using monoclonal antibodies. Arch. Virol. 90: 97110 .

2. Abenes, G. B., Kida, H. and Yanagawa, R. 1986. Biological activities of monoclonal antibodies to the hemagglutininneuraminidase (HN) protein of Newcastle disease virus. J. Vet. Med. Sci. 48: 353-362.

3. Alexander, D. J. 2008. Newcastle disease, other avian paramyxoviruses, and pneumovirus infections. pp.75-100. In: Diseases of Poultry, 12th ed. (Saif, Y.M., Barnes, H.J., Glisson, J.R., Fadly, A.M., McDougald, L.R. and Swayne, D.E. (eds.), Iowa State Press, Ames, Iowa.

4. Alexander, D. J., Campbell, G., Manvell, R. J., Collins, M. S., Parsons, G. and McNulty, M. S. 1992. Characterisation of an antigenically unusual virus responsible for two outbreaks of Newcastle disease in the Republic of Ireland in 1990. Vet. Rec. 130: $65-68$.

5. Alexander, D. J., Manvell, R., Banks, J., Collins, M. S., Parsons, G., Cox, B., Frost, K. M., Speidal, E. C., Ashman, S. and Aldous, E. W. 1999. Experimanetal assessment of the pathogenicity of the Newcastle disease viruses from outbreaks in Great Britain in 1997 for chickens and turkeys, and the protection afforded by vaccination. Avian Pathol. 28: 501-511.

6. Chambers, P., Millar, N. S. and Emmerson, P. T. 1986. Nucleotide sequence of the gene encoding the fusion glycoprotein of Newcastle disease virus. J. Gen. Virol. 67: 2685-2694.

7. Chambers, P., Nesbit, M., Yusoff, K., Millar, N. S., Samson, A. C. and Emmerson, P. T. 1988. Location of a neutralizing epitope for the haemagglutinin-neuraminidase glycoprotein of Newcastle disease virus. J. Gen. Virol. 69: 2115-2122.

8. Chen, L., Gorman, J. J., McKimm-Breschkin, J., Lawrence, L. J., Tulloch, P. A., Smith, B. J., Colman, P. M. and Lawrence, M. C. 2001. The structure of the fusion glycoprotein of Newcastle disease virus suggests a novel paradigm for the molecular mechanism of membrane fusion. Structure 9: 255-266.

9. Collins, M. S., Franklin, S., Strong, I., Meulemans, G. and Alexander, D. J. 1998. Antigenic and phylogenetic studies on a variant Newcastle disease virus using anti-fusion protein mon- 
oclonal antibodies and partial sequencing of the fusion protein gene. Avian Pathol. 27: 90-96.

10. Gelb, J., Jr., Fries, P. A. and Peterson, F. S. 1987. Pathogenicity and cross-protection of pigeon paramyxovirus-1 and Newcastle disease virus in young chickens. Avian Dis. 31: 601-606.

11. Gould, A. R., Hansson, E., Selleck, K., Kattenbelt, J. A., Mackenzie, M. and Della-Porta, A. J. 2003. Newcastle disease virus fusion and haemagglutinin-neuraminidase gene motifs as markers for viral lineage. Avian Pathol. 32: 361-373.

12. Imai, K., Tezuka, H. and Yuasa, N. 1986. Efficacy of Newcastle Disease (ND) Vaccine (B1 strain) against ND viruses Isolated in 1985 in Japan. J. Jpn. Soc. Poul. Dis. 22: 17-21 (in Japanese).

13. Imai, K., Yuasa, N., Kobayashp, S., Nakamura, K., Tsukamoto, K. and Hihara, H. 1990. Isolation of Marek's disease virus from Japanese quail with lymphoproliferative disease. Avian Pathol. 19: 119-129.

14. Iorio, R. M. and Bratt, M. A. 1984. Neutralization of Newcastle disease virus by monoclonal antibodies to the hemagglutinin-neuraminidase glycoprotein: requirement for antibodies to four sites for complete neutralization. J. Virol. 51: 445-451.

15. Kapczynski, D. R. and King, D. J. 2005. Protection of chickens against overt clinical disease and determination of viral shedding following vaccination with commercially available Newcastle disease virus vaccines upon challenge with highly virulent virus from the California 2002 exotic Newcastle disease outbreak. Vaccine 23: 3424-3433.

16. Ke, G. M., Yu, S. W., Ho, C. H., Chu, P. Y., Ke, L. Y., Lin, K. H., Tsai, Y. C., Liu, H. J. and Lin, M. Y. 2010. Characterization of newly emerging Newcastle disease viruses isolated during 2002-2008 in Taiwan. Virus Res. 147: 247-257.

17. Kim, L. M., King, D. J., Suarez, D. L., Wong, C. W. and Afonso, C. L. 2007. Characterization of class I Newcastle disease virus isolates from Hong Kong live bird markets and detection using real-time reverse transcription-PCR. J. Clin. Microbiol. 45: 1310-1314.

18. Kim, L. M., King, D. J., Curry, P. E., Suarez, D. L., Swayne, D. E., Stallknecht, D. E., Slemons, R. D., Pedersen, J. C., Senne, D. A., Winker, K. and Afonso, C. L. 2007. Phylogenetic diversity among low-virulence newcastle disease viruses from waterfowl and shorebirds and comparison of genotype distributions to those of poultry-origin isolates. J. Virol. 81: 1264112653.

19. Kwon, H. J., Cho, S. H., Ahn, Y. J., Seo, S. H., Choi, K. S. and Kim, S. J. 2003. Molecular epidemiology of Newcastle disease in Republic of Korea. Vet. Microbiol. 95: 39-48.

20. Lamb, R. A. and Kolakofsky, D. 2002. Pramyxoviridae: The viruses and their replication. pp. 1305-1340. In: Fundamental virology (Fields, B.B., Knipe, D.M. and Howley, P.M. (eds.).

21. Lee, Y. J., Sung, H. W., Choi, J. G., Kim, J. H. and Song, C. S. 2004. Molecular epidemiology of Newcastle disease viruses isolated in South Korea using sequencing of the fusion protein cleavage site region and phylogenetic relationships. Avian Pathol. 33: 482-491.

22. Letellier, C., Burny, A. and Meulemans, G. 1991. Construction of a pigeonpox virus recombinant: expression of the Newcastle disease virus (NDV) fusion glycoprotein and protection of chickens against NDV challenge. Arch. Virol. 118: 43-56.

23. Liang, R., Cao, D. J., Li, J. Q., Chen, J., Guo, X., Zhuang, F. F. and Duan, M. X. 2002. Newcastle disease outbreaks in western China were caused by the genotypes VIIa and VIII. Vet. Microbiol. 87: 193-203.

24. Liu, H., Wang, Z., Wu, Y., Zheng, D., Sun, C., Bi, D., Zuo, Y. and $\mathrm{Xu}$, T. 2007. Molecular epidemiological analysis of Newcastle disease virus isolated in China in 2005. J. Virol. Methods 140: 206-211.

25. Liu, H., Wang, Z., Wu, Y., Wu, Y., Sun, C., Zheng, D., Xu, T. and Li, J. 2008. Molecular characterization and phylogenetic analysis of new Newcastle disease virus isolates from the mainland of China. Res. Vet. Sci. 85: 612-616.

26. Liu, X. F., Wan, H. Q., Ni, X. X., Wu, Y. T. and Liu, W. B. 2003. Pathotypical and genotypical characterization of strains of Newcastle disease virus isolated from outbreaks in chicken and goose flocks in some regions of China during 1985-2001. Arch. Virol. 148: 1387-1403.

27. Mase, M., Inoue, T. and Imada, T. 2009. Genotyping of Newcastle disease viruses isolated from 2001 to 2007 in Japan. $J$. Vet. Med. Sci. 71: 1101-1104.

28. Mase, M., Imai, K., Sanada, Y., Sanada, N., Yuasa, N., Imada, T., Tsukamoto, K. and Yamaguchi, S. 2002. Phylogenetic analysis of Newcastle disease virus genotypes isolated in Japan. $J$. Clin. Microbiol. 40: 3826-3830.

29. McClelland, A. J. 1980. Vaccination against paramyxoviruses. Nature 284: 404.

30. McGinnes, L. W. and Morrison, T. G. 1986. Nucleotide sequence of the gene encoding the Newcastle disease virus fusion protein and comparisons of paramyxovirus fusion protein sequences. Virus. Res. 5: 343-356.

31. Merz, D. C., Scheid, A. and Choppin, P. W. 1980. Importance of antibodies to the fusion glycoprotein of paramyxoviruses in the prevention of spread of infection. J. Exp. Med. 151: 275288.

32. Meulemans, G., Gonze, M., Carlier, M. C., Petit, P., Burny, A. and Long, L. 1986. Protective effects of HN and F glycoprotein-specific monoclonal antibodies on experimental Newcastle disease. Avian Pathol. 15: 761-768.

33. Neyt, C., Geliebter, J., Slaoui, M., Morales, D., Meulemans, G. and Burny, A. 1989. Mutations located on both F1 and F2 subunits of the Newcastle disease virus fusion protein confer resistance to neutralization with monoclonal antibodies. $J$. Virol. 63: 952-954.

34. Ozai, Y., Komoda, M., Itoi, Y., Koizumi, S., Ogawa, T., Kubomichi, M. and Hatakeyama, H. 1987. Pathogenicity of Newcastle disease viruses (NDV) isolated from pigeons, chickens and pheasants, and the protective effect of vaccination of NDV strain B1. J. Vet. Med. Sci. 49: 523-525.

35. Qin, Z., Sun, L., Ma, B., Cui, Z., Zhu, Y., Kitamura, Y. and Liu, W. 2008. F gene recombination between genotype II and VII Newcastle disease virus. Virus Res. 131: 299-303.

36. Rui, Z., Juan, P., Jingliang, S., Jixun, Z., Xiaoting, W., Shouping, Z., Xiaojiao, L. and Guozhong, Z. 2010. Phylogenetic characterization of Newcastle disease virus isolated in the mainland of China during 2001-2009. Vet. Microbiol. 141: 246-257.

37. Russell, P. H., Griffiths, P. C., Goswami, K. K., Alexander, D. J., Cannon, M. J. and Russell, W. C. 1983. The characterization of monoclonal antibodies to Newcastle disease virus. J. Gen. Virol. 64: 2069-2072.

38. Sakaguchi, M., Nakamura, H., Sonoda, K., Hamada, F. and Hirai, K. 1996. Protection of chickens from Newcastle disease by vaccination with a linear plasmid DNA expressing the F protein of Newcastle disease virus. Vaccine 14: 747-752.

39. Taylor, J., Edbauer, C., Rey-Senelonge, A., Bouquet, J. F., Norton, E., Goebel, S., Desmettre, P. and Paoletti, E. 1990. Newcastle disease virus fusion protein expressed in a fowlpox virus recombinant confers protection in chickens. J. Virol. 64: 
1441-1450.

40. Toyoda, T., Gotoh, B., Sakaguchi, T., Kida, H. and Nagai, Y. 1988. Identification of amino acids relevant to three antigenic determinants on the fusion protein of Newcastle disease virus that are involved in fusion inhibition and neutralization. $J$. Virol. 62: 4427-4430.

41. Umino, Y., Kohama, T., Sato, T. A. and Sugiura, A. 1990. Protective effect of monoclonal antibodies to Newcastle disease virus in passive immunization. J. Gen. Virol. 71: 1199-1203.
42. Yu, L., Wang, Z., Jiang, Y., Chang, L. and Kwang, J. 2001. Characterization of newly emerging Newcastle disease virus isolates from the People's Republic of China and Taiwan. $J$. Clin. Microbiol. 39: 3512-3519.

43. Yusoff, K., Nesbit, M., McCartney, H., Meulemans, G., Alexander, D. J., Collins, M. S., Emmerson, P. T. and Samson, A. C. 1989. Location of neutralizing epitopes on the fusion protein of Newcastle disease virus strain Beaudette C. J. Gen. Virol. 70: 3105-3109. 